\title{
MDR1 C3435T POLYMORPHISM: A PRELIMINARY STUDY ON ITS RELATIONSHIP WITH THE RISK OF COLORECTAL CANCER
}

\author{
MDR1 C3435T POLIMORFIZMI: KOLOREKTAL KANSER RISKI ILE ILIŞKISI ÜZERINE BIR \\ ÖN ÇALIŞMA
}

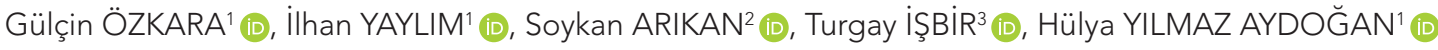 \\ ${ }^{1}$ Istanbul University, Aziz Sancar Institute of Experimental Medicine, Department of Molecular Medicine, Istanbul, Turkey \\ ${ }^{2}$ Istanbul Education and Research Hospital, General Surgery Clinics, Istanbul, Turkey \\ ${ }^{3}$ Yeditepe University, Faculty of Medicine, Department of Medical Biology and Genetics, Istanbul, Turkey
}

ORCID IDs of the authors: G.Ö. 0000-0002-4383-6890; I.Y. 0000-0003-2615-0202; S.A. 0000-0001-7132-6161; T.I. 0000-0002-7350-6032; H.Y.A. 0000-0002-8837-6664

Cite this article as: Ozkara G, Yaylim I, Arikan S, Isbir T, Yilmaz Aydogan H. MDR1 C3435T polymorphism: a preliminary study on its relationship with the risk of colorectal cancer. J Ist Faculty Med 2021;84(4):531-6. doi: 10.26650/IUITFD.2021.849990

\section{ABSTRACT}

Objective: Colorectal carcinoma (CRC) is the third most frequent cancer in the world and a heterogenious disease which aroze from one or a combination of different genetic mechanisms. The multiple drug resistance-1 (MDR1) gene which encodes P-glycoprotein (P-gp) plays a part in the bioavailability of drugs and cell toxicity. In the current study, we aimed to investigate the possible relation between the MDR1 gene C3435T polymorphism and $\mathrm{CRC}$ risk in the Turkish population.

Material and Methods: Forty three patients ( 26 men, 17 women) with CRC and 48 healthy controls (34 men, 14 women) were included in the study. The MDR1 C3435T genotypes were determined by the Restriction Fragment Length Polymorphism (RFLP) method.

Results: Statistical significance was obtained in terms of genotype distributions of MDR1 C3435T genotypes between study groups. The frequencies of MDR1 C3435T CC, TT and CT genotypes in the CRC patient group were found as $16.3 \%, 32.6 \%$ and $51.2 \%$, respectively. The frequency of the homozygous TT genotype was found as $32.6 \%$ in CRC patients while it was identified as $14.6 \%$ in controls ( $p=0.04 ; O R=2.82,95 \% \mathrm{Cl}: 1.01-7.87$ ). When the patients were compared with the healthy population, TT genotype carriers of MDR1 C3435T polymorphism were found at 2.8-fold $(p<0.05)$ increased risk for the development of CRC.

Conclusion: Our results show that the MDR1 C3435T polymorphism might be one of the genetic risk factors for CRC development in the Turkish population.

Keywords: MDR1, C3435T, polymorphism, colorectal cancer, Turkish population

\begin{abstract}
ÖZET
Amaç: Bir veya çoklu genetik mekanizmaların kombinasyonuyla oluşan heterojen bir hastalık olan kolorektal kanser (KRK) dünyada en sık görülen üçüncü kanserdir. P-glikoproteini (P-gP) kodlayan çoklu ilaç direnci geni-1 (Multiple drug resistance-1 (MDR1)) ilaçların biyoyararlanımı ve hücre toksisitesinde rol oynar. Bu çalışmada, Türk popülasyonunda MDR1 geni C3435T polimorfizmi ve KRK riski arasındaki olası ilişkiyi araştırmayı amaçladık.
\end{abstract}

Gereç ve Yöntemler: Çalışmamıza KRK hastası (26 erkek, 17 kadın) 43 kişi ve 48 sağlıklı kontrol (34 erkek, 14 kadın) dahil edilmiştir. MDR1 C3435T genotipleri Restriksiyon Fragman Uzunluk Polimorfizmi RFUP) yöntemiyle belirlenmiştir.

Bulgular: MDR1 C3435T genotiplerinin dağılımı açısından çaıışma grupları arasında istatistiksel anlamlılık elde edilmiştir. KRK hasta grubunda MDR1 C3435T CC, TT ve CT genotiplerinin sıklığı sırasıyla \%16,3, \%32,6 ve \%51,2 olarak bulunmuştur. Homozigot TT genotipi frekansı KRK hastalarında \%32,6 bulunurken kontrollerde \%14,6 ( $p=0,04 ; O R=2,82,95 \% \mathrm{Cl}$ : 1,01-7,87) olarak tespit edilmiştir. Hastalar ve sağlıklı kontroller karşılaştırıldığında MDR1 C3435T polimorfizmi TT genotipi taşıyıcıları KRK gelişimi için 2,8 kat $(p<0,05)$ artmış risk altında bulunmuştur.

Sonuç: Sonuçlarımız MDR1 C3435T polimorfizminin Türk popülasyonunda KRK gelişimi için genetik risk faktörlerinden biri olabileceğini göstermektedir.

Anahtar Kelimeler: MDR1, C3435T, polimorfizm, kolorektal kanser, Türk popülasyonu

Corresponding author/iletişim kurulacak yazar: gulcinozkara@gmail.com

Submitted/Başvuru: 30.12.2020 • Revision Requested/Revizyon Talebi: 19.05.2021 •

Last Revision Received/Son Revizyon: 20.05.2021 • Accepted/Kabul: 27.05.2021 • Published Online/Online Yayın: 29.09 .2021 


\section{INTRODUCTION}

Colorectal carcinoma (CRC) is the third most frequent cancer in the world which is responsible for $9.2 \%$ of death from cancer in both sexes according to Globocan 2018 data (1). Approximately $90 \%$ of the CRC cases are sporadic, while less than $10 \%$ of them have genetic predisposition (2). CRC is a heterogenious disease which arose from one or a combination of different genetic mechanisms, such as chromosomal instability (CIN), CpG island methylator phenotype (CIMP), or microsatellite instability (MSI) leading to malign transformation. Several genes are found in association with the risk of CRC development in numerous studies $(2,3)$.

Multidrug resistance (MDR) proteins are part of the ATP-binding cassette $(A B C)$ transporter superfamily and characterized as three different forms: atypical MDR, classical MDR and non-Pgp MDR (4). Many investigations have been performed regarding their function in transporting cytotoxic drugs out of the cell and their potential role as a target in cancer therapy (5).

The MDR1/ABCB1 gene which is known as the "Classical" MDR phenotype, is located on chromosome 7p21.12 and is highly polymorphic. It is first described in cancer cells and encodes P-glycoprotein (P-gp) which is a transmembrane protein with $170 \mathrm{kd}$ molecular weight $(6,7)$. $\mathrm{P}$-gp is principally expressed in the excretory organs like the kidney, liver, and intestines and promotes the excretion of drugs and xenobiotics into the bile and urine, thereby limiting intestinal drug absorption (8-10). Moreover, P-gp, as a gate-keeper of the blood-brain barrier, prevents the delivery of several drugs into the central nervous system (9).

Several single nucleotide polymorphisms (SNP) have been investigated within the MDR1 gene up to now. Most of them are found as intronic or silent, while some of them have been shown to be related to the changes in expression of the P-gp which affect tissue concentration of P-gp substrates (11-13).

A silent polymorphism in the middle of exon 26 of the MDR1 gene (C3435T) rs1045642 was found to be in relation with different types of human cancers such as breast, kidney, and liver (14-17). Reduced levels of the intestinal P-gp in TT genotype carriers was compared to subjects with CC genotype in the study of Hoffmeyer et al. (11). Contrary to several studies which demonstrated the relation between the 3435TT genotype and decreased levels of P-gp expression, Nakamura et al. found that the CC genotype was associated with decreased P-gp expression levels (11-13). Ethnic differences in allelic frequencies of the C3435T polymorphism were also observed (18-20).
The aim of the current study was to investigate the possible association between MDR1 C3435T SNP and CRC development in the Turkish population.

\section{MATERIALS AND METHODS}

\section{Patient selection}

Forty-three CRC patients (26 men, 17 women) diagnosed by radiologic and endoscopic methods, and surgical findings together with a pathologic examination were included in the study. Collection of blood samples were performed before cancer therapy. Patients who applied for non-neoplastic diseases such as trauma or inguinal hernia to general surgery and orthopedia clinics in the same hospital were included in the control group (34 men, 24 women). Ethical approval of the study was obtained from the Ethical Committee of the Istanbul Education and Research Hospital (Date: 23.06.2017, No: 1015). All procedures involving human participants were in accordance with the ethical standards of the institutional committee and the Declaration of Helsinki. Written informed consent was received from all participants prior to collecting their biological samples.

\section{DNA extraction}

Blood samples were collected into EDTA containing tubes, and the DNA was isolated from peripheral blood according to a salting out procedure (21).

\section{Genotyping}

Genotypes of the MDR1 C3435T polymorphism were identified with a restriction fragment length polymorphism (RFLP) (22). The following primer sets were used for polymerase chain reaction (PCR); P1 (5'-ACTCTTGTTTTCAGCTGCTTG-3') and P2 (5'-AGAGACTTACATTAGGCAGTGACTC-3'). PCR was carried out using $200 \mathrm{ng}$ of DNA, $200 \mu \mathrm{mol} / \mathrm{l}$ of dATP, dCTP, dGDP and TTP (MBI Fermantas, Vilnius, Lithuania), $250 \mathrm{ng}$ of primers; $1.5 \mathrm{mmol} / \mathrm{l}$ of magnesium chloride, and $2 \mathrm{U}$ of Taq DNA polymerase (MBI Fermantas, Vilnius, Lithuania) in a total volume of $100 \mu \mathrm{l}$ at GeneAmp PCR Systems 9700 thermal cycler (Perkin Elmer). Cycling conditions of PCR were as follows: $94^{\circ} \mathrm{C}(2 \mathrm{~min})$ (initial denaturation) followed by 35 cycles at $94^{\circ} \mathrm{C}(30 \mathrm{~s})$ (denaturation), at $56^{\circ} \mathrm{C}\left(30 \mathrm{~s}\right.$ ) (annealing), and at $72^{\circ} \mathrm{C}(30 \mathrm{~s}$ ) (extension). The terminal elongation step was applied at $72^{\circ} \mathrm{C}$ (7 min). The C3435T genotypes were determined by digestion of a PCR product with Dpnll (Mbol) restriction enzyme at $37^{\circ} \mathrm{C}(4 \mathrm{~h})$. Agarose gel with a density of $3 \%$ was used for seperation of DNA fragments.

\section{Statistical analysis}

SPSS (version 20.0) was used for statistical analyses. A chi-square test $\left(X^{2}\right)$ was performed for the comparison of genotype and allele distributions in study groups. 'Gene counting methods' were performed for the calculation of allele frequencies. Biochemical features of the study 
groups were compared by the Mann Whitney $U$ test. A $\mathrm{p}$-value of less than 0.05 was considered for statistical significance.

A sample size calculation was performed using the "PS Power and Sample Size Calculation" package program, with inputs of $\mathrm{p0}$ (probability of exposure in controls) and p1 (probability of exposure in cases) from the Ensemble genome browser. The type I error probability $(\alpha)$ was used as 0.05. The statistical power of the relationship between SRBI rs5888, rs4238 MDR1 C3435T variation and colorectal cancer risk was obtained as $52.7 \%$ in the study.

\section{RESULTS}

Demographic and biochemical features of the study groups are given in Table 1. Mean age of the control subjects and CRC patients were $57.31 \pm 9.99$ years and $54.55 \pm 13.44$ years, respectively. Sex and age frequencies were similar in both groups. Alanine transaminase $(A L T)(p<0.001)$, alkaline phosphatase $(A L P)$, and blood urea nitrogen $(B U N)(p<0.001)$ values were found higher in CRC group as compared to the control. The MDR1 C3435T genotype and allele frequencies of the study groups are presented in Table 2. The genotype distributions were found to be significantly different between CRC patients and the control group. The frequencies of the CC, TT and CT genotypes of MDR1 C3435T among CRC patients were $16.3 \%, 32.6 \%$ and $51.2 \%$, respectively. The homozygous TT genotype was identified in $32.6 \%$ of CRC patients while it was found in only $14.6 \%$ in the control group ( $p=0.04 ; O R=2.82,95 \% \mathrm{Cl}: 1.01-7.87)$. The heterozygous genotype (CT) was observed in $51.2 \%$ of CRC patients while it was detected in $68.8 \%$ among the control group.

\section{DISCUSSION}

The product of the MDR1 gene, P-gp, which is an integral membrane protein, actively transports relevant drugs

from the inside to the outside of the cell, thereby playing a role in preventing the accumulation of toxic and carcinogenic substances inside the cell $(9,10,23,24)$. It also limits success of cancer therapy by removing chemotherapeutic drugs from tumor cells (25). In several cancer studies, P-gp over-expression has been related to the poor outcome of chemotheraphy in breast cancer, acute myeloid leukaemia, and childhood tumors $(10,16,26)$. Altered P-gp expression and function due to genetic polymorphisms as well as physiological and environmental factors have been identified in several studies $(8,26,27)$.

The C3435T is a "silent" polymorphism which has no effect on the amino acid sequence of the MDR1 gene and is not expected to have a direct effect on P-gp expression $(18,28)$. The C3435T polymorphism has been found to have different effects on gene expression and protein formation in previous studies. This synonymous polymorphism could show its effect by involving in different mechanisms such as mRNA splicing, protein folding, and modification of translation efficiency $(11-13,28,29)$.

Table 2: Genotype and allele frequencies of MDR1 C3435T in the study groups

\begin{tabular}{lcc}
\hline Group & $\begin{array}{c}\text { Control } \\
(\mathbf{n}=\mathbf{4 8})\end{array}$ & $\begin{array}{c}\text { CRC patients } \\
(\mathbf{n}=\mathbf{4 3})\end{array}$ \\
\hline Genotypes & & \\
CC & $16.7 \%(8)$ & $16.3 \%(7)$ \\
TT & $14.6 \%(7)$ & $32.6 \%(14)^{*}$ \\
CT & $68.8 \%(33)$ & $51.2 \%(22)$ \\
Alleles & & \\
C & $51.04 \%(49)$ & $41.86 \%(36)$ \\
T & $48.95 \%(47)$ & $58.13 \%(50)$ \\
\hline n: number of individuals, CRC: Colorectal Cancer; ${ }^{*}, p=0.04 ;$ \\
OR=2.82 95\% Cl:1.01-7.87
\end{tabular}

Table 1: Demographic and clinical features of the study groups

\begin{tabular}{lccc}
\hline & Control $(\mathbf{n = 4 8})$ & CRC patients $(\mathbf{n = 4 3 )}$ & p value \\
\hline Age (year) & $57.31 \pm 1.44$ & $54.55 \pm 2.87$ & 0.621 \\
Sex (female/male, $n)$ & $17 / 26$ & 0.297 \\
Smoking (\%) & $14 / 34$ & 33.3 & 0.933 \\
ALT (U/L) & 34.5 & $44.70 \pm 2.97$ & $\mathbf{0 . 0 0 1}$ \\
AST (U/L) & $32.50 \pm 9.31$ & $26.10 \pm 4.93$ & 0.409 \\
ALP (U/L) & $23.67 \pm 1.57$ & $102.11 \pm 4.55$ & $\mathbf{0 . 0 3 9}$ \\
Creatinine (mg/dL) & $79.50 \pm 9.12$ & $0.92 \pm 0.07$ & 0.616 \\
BUN (mg/dL) & $0.78 \pm 0.02$ & $1.13 \pm 0.28$ & $\mathbf{0 . 0 0 1}$ \\
\hline
\end{tabular}

The results are shown as mean \pm SEM (standard error). Mann Whitney $U$ test was performed for the comparison between groups. $\mathrm{n}$ : number of individuals, CRC: Colorectal Cancer, ALT: Alanine transaminase, AST: Aspartate transaminase, ALP: alkaline phosphatase, BUN: Blood urea nitrogen 
In the study of Hoffmeyer et al, it was firstly showed that the MDR1 C3435T polymorphism was associated with MDR1 expression in the human duodenum. The study indicated that 3435TT carriers have decreased expression and P-gp function (11). Similarly, in the study of Eichelbaum et al. lower P-gp expression and function was found in MDR1 3435 TT genotype carriers (28). Some studies demonstrated the relation between the 3435TT genotype and decreased levels of P-gp expression, while Nakamura et al. found a positive correlation between CC genotype and decreased P-gp expression (11-13, 28).

There are several studies investigating the relationship between the MDR1 C3435T polymorphism and CRC risk $(8,12,31,32)$. Kurzawski et al. first reported that carriers of the MDR1 3435TT genotype in the Polish population have a 2.7-fold increased risk for colon cancer development (12). Similarly, Ambudkar et al. showed that the MDR1 3435TT genotype is associated with an increased risk of developing CRC (8). The increased risk has been attributed to the formation of functional defects in the barrier of epithelial cells as a result of downregulation of $\mathrm{P}-\mathrm{gp}$ and thus exposure of patients to higher damaging toxin levels (8). Humeny et al. studied the C3435T polymorphism in tumor and normal tissues of CRC patients, and reported no change in the genotypic frequency of polymorphism between tumor and normal samples during colorectal tumorigenesis (30).

Zhao et al. performed a meta-analysis study including 5,485 cases and 5,854 controls and found no significant associations between the ABC1/ MDR1 C3435T polymorphism and CRC susceptibility by obtaining similar results for both Caucasian and Asian populations (31). However, in the the meta-analysis study of Jin et al. including 4818 individuals, T allele carriers of the MDR1 C3435T polymorphism had significant lower risk for CRC development in the Asian population according to both homozygous comparison (TT vs CC) and recessive model (TT vs TC+CC). (32). In the study of Ozhan et al., although no significant association was observed between the C3435T polymorphism and CRC risk in the Turkish population, the ABCB1 haplotype $\mathrm{C}_{1236}-\mathrm{G}_{2677^{-}}-T_{3435}$ was found significantly more frequently in CRC patients as compared to the control group $(p=0.0004, O R=11.96$, 95\% Cl=2.59-55.32) in the haplotype-based analysis (33). The effect of SNPs on CRC development differs according to ethnicity in various studies in the literature. As an example, the MDM2 SNP309 and x-ray repair cross-complementing group 1 (XRCC1) Arg399G In SNPs were found associated with the risk of CRC in the Asian population, while the same results were not found in European populations $(34,35)$. Additionally, in the study of Wang et al., the frequency of the MDR1 3435TT allele among healthy individuals was found to be higher in Asians and Caucasians ((27.8\%, 49.4\% respectively) (36).
In the present study, the distrubution of the C3435T alleles in CRC patients was significantly different from healthy subjects. According to the results of this study, a 2.8-fold increased risk was found for CRC development in patients who have the TT genotype of MDR1 C3435T polymorphism. This finding may support the hypothesis that the 3435TT genotype plays a negative role in the expression of $\mathrm{P}$-gp which is involved in the defense mechanism against detrimental compounds and carcinogens. However, the frequency of genotypes in the present study were found to be different from previous studies (19-21, 31, 36). Half of the individuals were heterozygous carriers of the variant, while more than $32 \%$ were homozygous carriers of the variant in the patient group. Also, this control group showed a different distribution of genotypes as compared with other studies. The difference might be due to the different number of subjects and/or different ethnic populations as well as the heterogenous nature of the disease and the effect of environmental factors.

The major limitation of the study includes small sized study groups. In order to shed more light on the association of the MDR1 C3435T polymorphism with CRC risk, this work would be better extended with a larger study group that includes the results of this polymorphism on the expression levels of the MDR1 gene and protein levels.

To conclude, this is a preliminary study to demonstrate whether the MDR1 C3435T polymorphism has an effect in CRC pathogenesis in the the Turkish population. Based on these findings, we propose that the MDR1 gene C3435T polymorphism had a possible effect in the development of CRC in the Turkish population.

Ethics Committee Approval: This study was approved by the Clinical Research Ethical Committee of the Istanbul Education and Research Hospital (Date: 23.06.2017, No: 1015).

Informed Consent: Written consent was obtained from the participants.

Peer Review: Externally peer-reviewed.

Author Contributions: Conception/Design of Study- H.Y.A., I.Y.; Data Acquisition- S.A., G.Ö., I.Y.; Data Analysis/Interpretation- H.Y.A., T.i.; Drafting Manuscript- G.Ö., I.Y., S.A., T.I., H.Y.A.; Critical Revision of Manuscript- H.Y.A., T.I.; Final Approval and Accountability- G.Ö., I.Y., S.A., T.I., H.Y.A.

Conflict of Interest: Authors declared no conflict of interest.

Financial Disclosure: Authors declared no financial support.

Etik Komite Onayı: Bu çalışma için etik komite onayı İstanbul Eğitim ve Araştırma Hastanesi Klinik Araştırmalar Etik Kurulu'ndan alınmıştır (Tarih: 23.06.2017, No: 1015). 
Bilgilendirilmiş Onam: Katılımcılardan bilgilendirilmiş onam alınmıştır.

\section{Hakem Değerlendirmesi: Dış bağımsız.}

Yazar Katkıları: Çalışma Konsepti/Tasarım- H.Y.A., I.Y.; Veri Toplama S.A., G.Ö., I.Y.; Veri Analizi/Yorumlama- H.Y.A., T.I.; Yazı Taslağı- G.Ö., I.Y., S.A., T.I., H.Y.A.; İçeriğin Eleştirel İncelemesiH.Y.A., T.I.; Son Onay ve Sorumluluk- G.Ö., I.Y., S.A., T.I., H.Y.A.

Çıkar Çatışması: Yazarlar çıkar çatışması beyan etmemişlerdir.

Finansal Destek: Yazarlar finansal destek beyan etmemişlerdir.

\section{REFERENCES}

1. Bray F, Ferlay J, Soerjomataram I, Siegel RL, Torre LA, Jemal A. Global cancer statistics 2018:GLOBOCAN estimates of incidence and mortality worldwide for 36 cancers in 185 countries. CA: A Cancer Journal for Clinicians 2018;68(6):394-424. [CrossRef]

2. Bogaert J, Prenen $\mathrm{H}$. Molecular genetics of colorectal cancer. Ann Gastroenterol 2014;27(1):9-14.

3. Tariq K, Ghias K. Colorectal cancer carcinogenesis: a review of mechanisms. Cancer Biol Med 2016;13(1):120-35. [CrossRef]

4. Nooter K, Stoter G. Molecular mechanisms of multidrug resistance in cancer chemotherapy. Pathol Res Pract 1996;192(7):768-80. [CrossRef]

5. Cole SP, Bhardwaj G, Gerlach JH, Mackie JE, Grant CE, Almquist $\mathrm{KC}$, et al. Overexpression of a transporter gene in a multidrug-resistant human lung cancer cell line. Science 1992;258(5088):1650-4. [CrossRef]

6. Gottesman MM, Fojo T, Bates SE. Multidrug resistance in cancer: role of ATP-dependent transporters. Nat Rev Cancer 2002;2(1):48-58. [CrossRef]

7. Jordan A, Scholz R. Selection and characterization of heatresistant variants of multidrug-resistant human gastric carcinoma cell lines. Exp Oncol 2005;27(1):18-23.

8. Ambudkar SV, Kimchi-Sarfaty C, Sauna ZE, Gottesman MM. P-glycoprotein: from genomics to mechanism. Oncogene 2003;22(47):7468-85. [CrossRef]

9. Schinkel $\mathrm{AH}$. The physiological function of drugtransporting P-glycoproteins. Semin Cancer Biol 1997;8(3):161-70. [CrossRef]

10. Lockhart AC, Tirona RG, Kim RB. Pharmacogenetics of ATPbinding cassette transporters in cancer and chemotherapy. Mol Cancer Ther 2003;2(7):685-98.

11. Hoffmeyer $S$, Burk $O$, von Richter $O$, Arnold HP, Brockmoller J, Johne A. Functional polymorphisms of the human multidrug-resistance gene: multiple sequence variations and correlation of one allele with P-glycoprotein expression and activity in vivo. Proc Natl Acad Sci U S A 2000;97(7):3473-8. [CrossRef]

12. Kurzawski M, Drozdzik M, Suchy J, Kurzawski G, Bialecka M, Gornik W, et al. Polymorphism in the P-glycoprotein drug transporter MDR1 gene in colon cancer patients. Eur J Clin Pharmacol 2005;61(5-6):389-94. [CrossRef]

13. Nakamura T, Sakaeda T, Horinouchi M, Tamura T, Aoyama $N$, Shirakawa T, et al. Effect of the mutation (C3435T) at exon 26 of the MDR1 gene on expression level of MDR1 messenger ribonucleic acid in duodenal enterocytes of healthy Japanese subjects. Clin Pharmacol Ther 2002;71(4):297-303. [CrossRef]
14. Turgut S, Yaren A, Kursunluoglu R, Turgut G. MDR1 C3435T polymorphism in patients with breast cancer. Arch Med Res 2007;38(5):539-44. [CrossRef]

15. Taheri M, Mahjoubi F, Omranipour R. Effect of MDR1 polymorphism on multidrug resistance expression in breast cancer patients. Genet Mol Res 2010;9(1):34-40. [CrossRef]

16. Siegsmund M, Brinkmann U, Scháffeler E, Weirich G, Schwab M, Eichelbaum M, et al. Association of the P-glycoprotein transporter MDR1 (C3435T) polymorphism with the susceptibility to renal epithelial tumors. J Am Soc Nephrol 2002;13(7):1847-54. [CrossRef]

17. Baldissera VD, de Mattos AA, Corral GP, de Araujo FB, Marroni CA, de Mello Brandao AB, et al. Evaluation of the C3435T polymorphisim in the MDR1 gene in patients with hepatocellular carsinoma. Ann Hepatol 2012;11(6):899-906. [CrossRef]

18. Ozawa S, Soyama A, Saeki M, Fukushima-Uesaka H, Itoda $\mathrm{M}$, Koyano $\mathrm{S}$, et al. Ethnic differences in genetic polymorphisms of CYP2D6, CYP2C19, CYP3As and MDR1/ ABCB1.Drug Metab Pharmacokinet 2004;19(2):83-95. [CrossRef]

19. Cascorbi I, Gerloff Th, Johne A, Meisel CH, Hoffmeyer S, Schwab M. Frequency of single nucleotide polymorphisms in the P-glycoprotein drug transporter MDR1 gene in white subjects. Clin Pharmacol Ther 2001;69(3):169-74. [CrossRef]

20. Tan EK, Drozdzik M, Bialecka M, Honczarenko K, KlodowskaDuda G, Teo YY, et al. Analysis of MDR1 haplotypes in Parkinson's disease in a white population. Neurosci Lett 2004;372(3):240-4. [CrossRef]

21. Miller SA, Dykes DD, Polesky HS. Simples salting out procedure for extracting DNA from human nucleated cells. Nucleic Acid Res 1988;16(3):1215. [CrossRef]

22. Sills GJ, Mohanraj R, Butler E, McCrindle S, Collier L, Wilson EA, et al. Lack of association between the C3435T polymorphism in the human multidrug resistance (MDR1) gene and response to antiepileptic drug treatment. Epilepsia 2005;46(5):643-7. [CrossRef]

23. Ho GT, Moodie FM, Satsangi J. Multidrug resistance 1 gene (P-glycoprotein 170):an important determinant in gastrointestinal disease. Gut 2003;52(5):759-66. [CrossRef]

24. Tanigawara Y. Role of P-glycoprotein in drug disposition. Ther Drug Monit 2000;22(1):137-40. [CrossRef]

25. Jamroziak K, Młynarski W, Balcerczak E, Mistygacz M, Trelinska J, Mirowski M, et al. Functional C3435T polymorphism of MDR1 gene:an impact on genetic susceptibility and clinical outcome of childhood acute lymphoblastic leukemia. Eur J Haematol 2004;72(5):314-21. [CrossRef]

26. Illmer T, Schuler US, Thiede C, Schwarz UI, Kim RB, Gotthard S, et al. MDR1 gene polymorphisms affect therapy outcome in acute myeloid leukemia patients. Cancer Res 2002;62(17):4955-62.

27. Drescher S, Schaeffeler E, Hitzl M, Hofmann U, Schwab $M$, Brinkmann $U$, et al. MDR1 gene polymorphisms and disposition of the P-glycoprotein substrate fexofenadine. Br J Clin Pharmacol 2002;53(5):526-34. [CrossRef]

28. Eichelbaum M, Fromm MF, Schwab M. Clinical aspects of the MDR1 (ABCB1) gene polymorphism. Ther Drug Monit 2004;26(2):180-5. [CrossRef] 
29. Jeleń AM, Sałagacka A, Żebrowska MK, Mirowski M, Talarowska M, Gałecki P, et al. The influence of C3435T polymorphism of the ABCB1 gene on genetic susceptibility to depression and treatment response in Polish population Preliminary Report. Int J Med Sci 2015;12(12):974-9. [CrossRef]

30. Humeny A, Rodel F, Rodel C, Sauer R, Fuzesi L, Becker C. MDR1 single nucleotide polymorphism C3435T in normal colorectal tissue and colorectal carcinomas detected by MALDI-TOF mass spectrometry. Anticancer Res 2003;23(3B):2735-40.

31. Zhao L, Li K, Li W, Yang Z. Association between the C3435T polymorphism of ABCB1/MDR1 gene (rs1045642) and colorectal cancer susceptibility. Tumor Biol 2013;34 (3):1949-57. [CrossRef]

32. Jin SS, Song WJ. Association between MDR1 C3435T polymorphism and colorectal cancer risk: A meta-analysis. Medicine (Baltimore) 2017;96(51):e9428. [CrossRef]
33. Özhan G, Kara M, Sari FM, Yanar HT, Ercan G, Alpertunga B. Associations between the functional polymorphisms in the $A B C B 1$ transporter gene and colorectal cancer risk: a case-control study in Turkish population. Toxicology Mechanisms and Methods 2013;23(4):235-9. [CrossRef]

34. Fu Q, Zhang G, Chen H, Zheng Y, Cheng J. Current evidence on the relationship between SNP309 polymorphism in the MDM2 gene and colorectal cancer risk. Tumour Biol 2013;34(6):3721-9. [CrossRef]

35. Zeng FR, Ling Y, Yang J, Tian XC, Yang X, Luo RC. X-ray repair cross-complementing group 1 Arg399GIn gene polymorphism and susceptibility to colorectal cancer:a meta-analysis. Tumour Biol 2013;34(1):555-63. [CrossRef]

36. Wang J, Wang B, Bi J, Li K, Di J. MDR1 gene C3435T polymorphism and cancer risk: a meta-analysis of 34 casecontrol studies. J Cancer Res Clin Oncol 2012;138(6):97989. [CrossRef] 